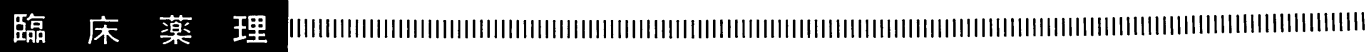

\title{
外科領域における脱線維素療法の可能性について*
}

\begin{tabular}{|c|c|c|c|c|c|c|c|}
\hline 丸 & 新** & 友 成 & 正 & 紀** & 百目木 & 公 & 一** \\
\hline 池 & 介** & 原 & 靖 & 之** & 堀 & 泰 & 良** \\
\hline 欽 & 一** & 橋 & 雅 & 俊** & 藤 & & 男*** \\
\hline
\end{tabular}

Key words : defibrase, defibrination therapy, fibrinogen, FDP, thrombin like enzyme.

はじめに

蛇毒より精製された thrombin like enzyme による脱線維素療法は血栓性疾患に対する一種 の抗凝固療法として近年ヨーロッパを中心に注 目され検討がすすめられている.

血栓性疾患に対する薬物治療には一定の限界 があるが，その効果を高めるために必要な条件 としては既に形成されている血栓に対する溶解 力と新しい血栓の形成を防止する能力のいかん にある．しかし優れた薬理作用があっても生体 にとって出血の危惧があってはならないことは 当然である.脱線維素療法がこれらをすべて満 足しているかどうかについては疑問な点もある が，従来の方法とは異なった新しい型の抗凝固 療法としてその効果が期待されている.

われわれは今回 Bothrops atrox marajoensis （スズヘビ）のもつ蛇毒より精製された Defibrase (Pentapharm 社) について, その血液凝 固および線溶系への影響を観察し，さらにこの 抗凝固性について検討するとともに Defibrase が血行再建術などの外科手術後の抗凝固療法と して使用可能かどうかについて実験的検討を行 ったので報告する.

\section{I. 実験目的および方法}

\section{Defibrase による血液凝固 および 線溶系 の変化について}

雑種成犬 21 頭を使用し，このうちの 11 頭に は Defibrase (Bothrops atrox marajoensis) Lot. 696 の $50 \mu \mathrm{l} / \mathrm{kg}$ を $100 \mathrm{~m} l$ 生食水に溶解し約 60 分間で点滴静注した。 また残り 10 頭にはDefibrase $100 \mu \mathrm{l} / \mathrm{kg}$ を同様にして投与し，各群に ついて投与前，投与後 1 時間， 2 時間， 4 時 間, 6 時間, 10 時間, 24 時間に, それぞれ静 脈採血して下記の諸検査を行った.

(1) 赤血球数.

(2) ヘマトクリット.

(3) 血小板数 (Brecher-Cronkit 法).

(4) フィブリノゲン (重量法).

(5) プロトロンビン時間 (Quick I 段法).

(6) 活性化部分トロンボプラスチン時間（プ ラテリンプラスアクチベータを使用).

(7) 各凝固因子定量 (II, V, VII-X, VIII, IX 因子).

(8) FDP (Thrombo-wellcotest).

(9) プラスミノゲン, 活性プラスミン, 抗プ ラスミン (Affinity fibrin plate test).

* Studies on possibility of surgery during defibrination therapy.

** 東京医科大学外科, Shin ISHIMARU, Masaki TOMONARI, Kinichi DOMEKI, Sosuke KOIKE, Yasuyuki FUJIWARA, Yasuyoshi HORIGUCHI, Kinichi FURUKAWA and Masatoshi TAKAHASHI : Department of Surgery, Tokyo Medical College, Tokyo, Japan.

*** 同・臨床病理, Michio FUJIMAKI : Department of Clinical Pathology. 

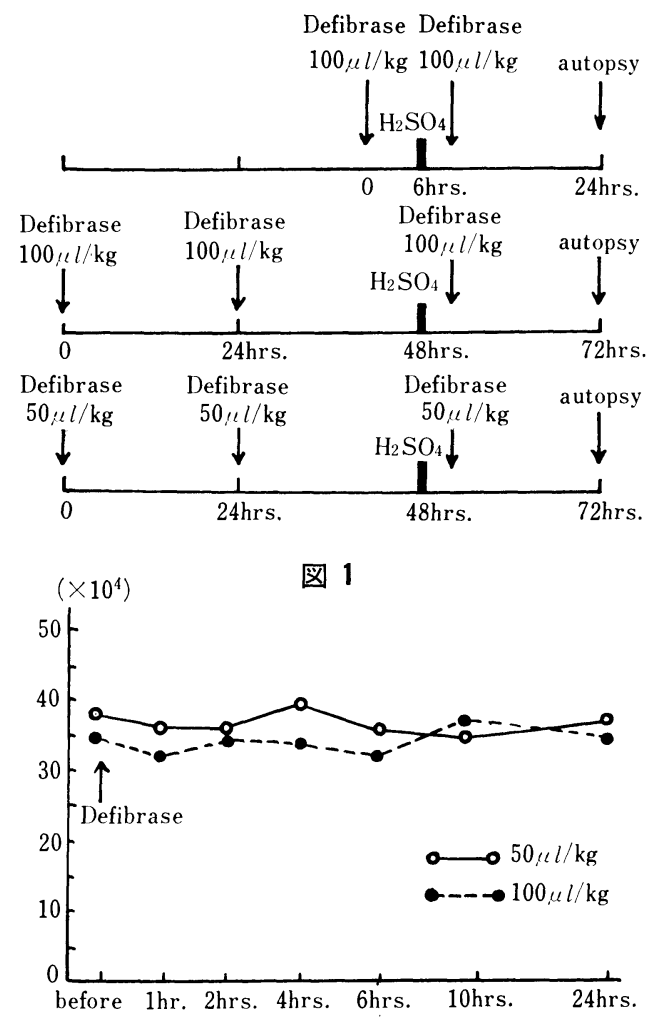

図 3 Platelet count.

(10) 硫酸プロタミン試験 (Lipinski).

さらに両群について 1 日 1 回の投与を 3 日間 続け，同様な検査を行った.

\section{2. 実験的血栓形成モデルによる Defibrase の血栓阻止効果について.}

雑種成犬 20 頭を用い, 大腿動脈を露出して これを約 $2 \mathrm{~cm}$ にわたり中枢側と末梢側の 2 力 所で遮断し，27G 注射針にてこの間の血管内血 液を除去した後に $5 \% \mathrm{H}_{2} \mathrm{SO}_{4}$ を注入し，2 分 間放置してから生食水洗涤を行い血流を再開す るが酸によって血管内膜に損傷を与えることで 同部の大腿動脈には血栓形成モデルが作成され る.10頭の血栓形成群をコントロール群とし,前 処置として Defibrase を投与した群 (Defibrase $100 \mu \mathrm{l} / \mathrm{kg}$ 投与 2 頭, Defibrase $100 \mu \mathrm{l} / \mathrm{kg} 2$ 日 間投与 2 頭， Defibrase $50 \mu \mathrm{l} / \mathrm{kg} 2$ 日間投与 6 頭）について実験を行った．血栓形成モデルの 作成は Defibrase 前投与後 6 時間から 24 時間内 に行われたが，その後 24 時間における 早期血

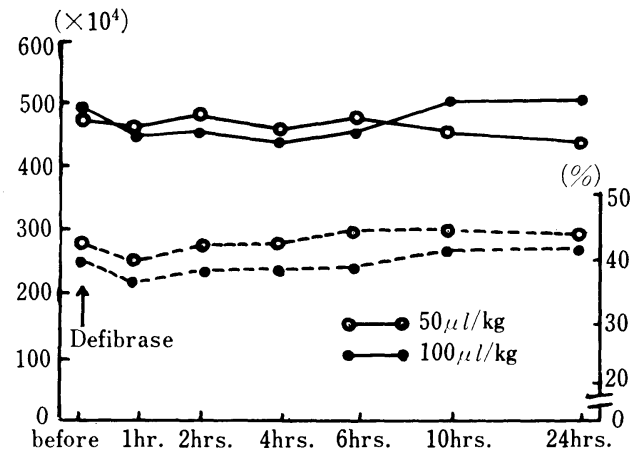

図 $2 \mathrm{RBC}$ and $\mathrm{Ht}$.

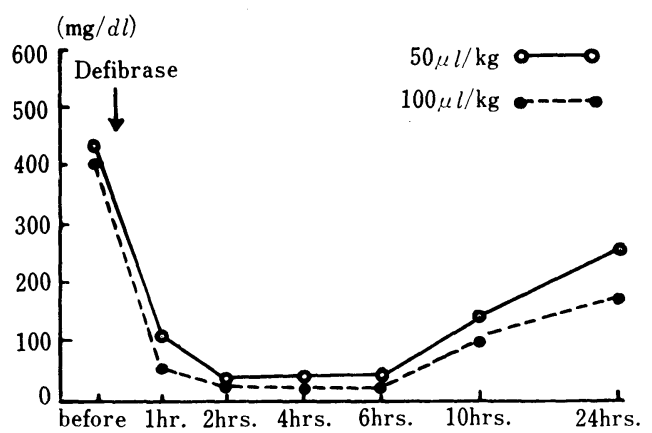

図 4 Fibrinogen level.

栓形成状態を観察した。 なお，Defibrase 投与 群ではモデル作成後 2 時間で同量の Defibrase を追加投与した（図 1 ).

3. Defibrase 投与中の外科的侵襲による出 血について（外科的侵襲の可能性につい て)

Defibrase $100 \mu \mathrm{l} / \mathrm{kg} 1$ 回投与群, $100 \mu \mathrm{l} / \mathrm{kg}$ 2 日間投与群， $50 \mu \mathrm{l} / \mathrm{kg} 2$ 日間投与群の各々 について出血の状態と, その対策について検討 した.

\section{II. 実験結果}

\section{1. 凝固線溶系変化}

1） Defibrase 1 回投与による変化について.

(1) 赤血球数およびへマトクリット：Defibrase 投与前では赤血球数 $480 \pm 105 \times 10^{4} / \mathrm{mm}^{3}$, ヘマトクリット值 $42 \pm 11 \%$ であり， Defibrase 投与後も殆どこの值に変化をみず，Defibrase 投与量による変化もみられなかった(図 2 ).

(2) 血小板数 : 投与前值 $38.0 \pm 14.0 \times 10^{4} /$ 
$6: 990$
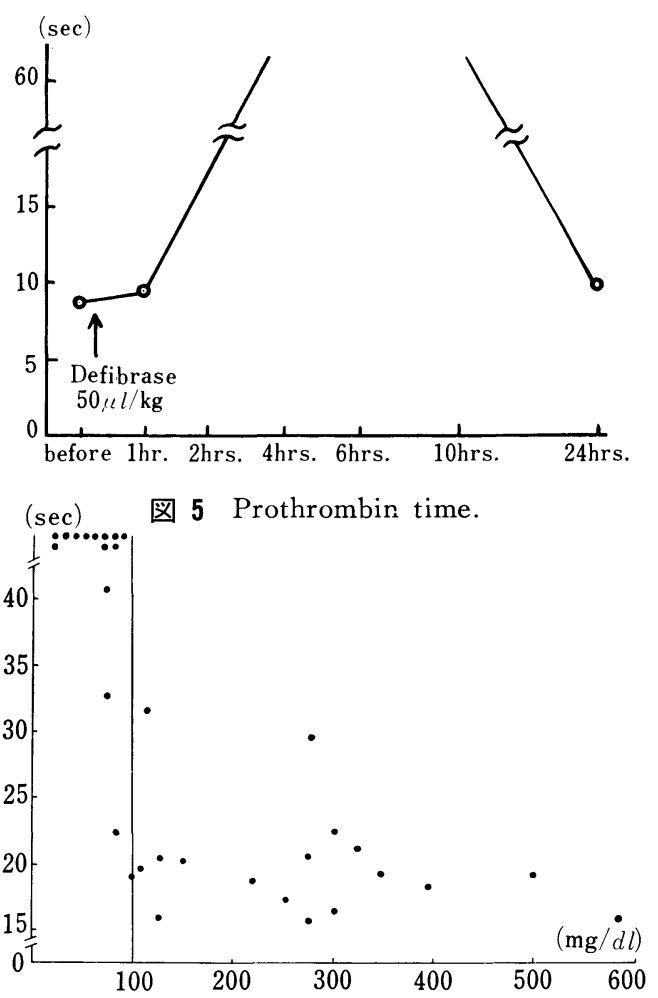

図 7 Fibrinogen and A-PTT.

$\mathrm{mm}^{3}$ であり投与後もほとんどこの值に変化な く, 投与量による変化もみられなかった（図 3 ).

(3) フィブリノゲン：投与前值 $408 \pm 122 \mathrm{mg} /$ $\mathrm{d} l$ で Defibrase $50 \mu l / \mathrm{kg}$ 投与群では投与後 1 時 間で $100 \mathrm{mg} / \mathrm{d} l$ 前後となり， 2 時間後および 4 時間後には測定不能 $(30 \mathrm{mg} / \mathrm{d} l$ 以下） となっ た.さらに 10 時間後では $130 \mathrm{mg} / \mathrm{d} l$ 前後と回 復をみせ, 24 時間後には $250 \mathrm{mg} / \mathrm{d} l$ 前後まで に回復した。 また Defibrase $100 \mu$ ? $/ \mathrm{kg}$ 投与群 では，投与後 1 時間で $50 \mathrm{mg} / \mathrm{d} l$ 前後に減少， 2 時間以後 6 時間後まで測定不能であり，投与 後 10 時間より次第に回復しはじめ, 24 時間後 では $150 \mathrm{mg} / \mathrm{d} l$ と回復しており，投与量の多い 方がフィブリノゲンの減少程度が大きい傾向に あった．しかしいずれもかなりのバラツキがあ り投与後 6 時間でも $120 \mathrm{mg} / \mathrm{d} l$ 前後の高値を示 すものや, 投与後 24 時間で $250 \mathrm{mg} / \mathrm{d} l$ 以上に 回復するものもみられた(図 4).

(4) プロトロンビン時閒 $(\mathrm{PT})$ : Defibrase 50
血液と脈管第 6 巻第 12 号

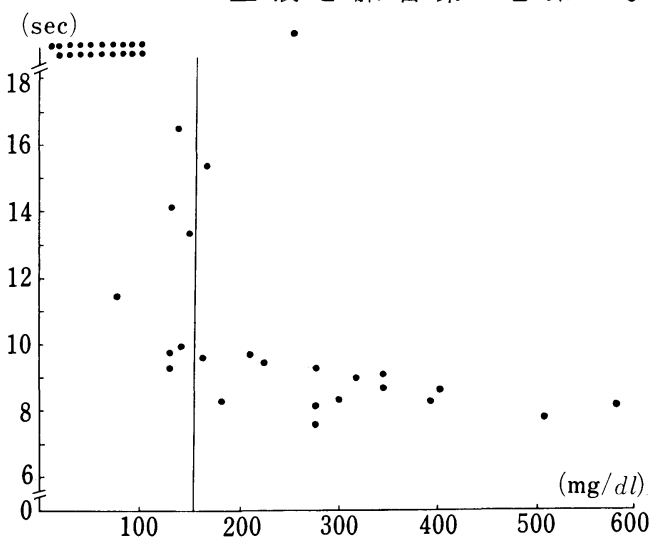

図 6 Fibrinogen and PT.

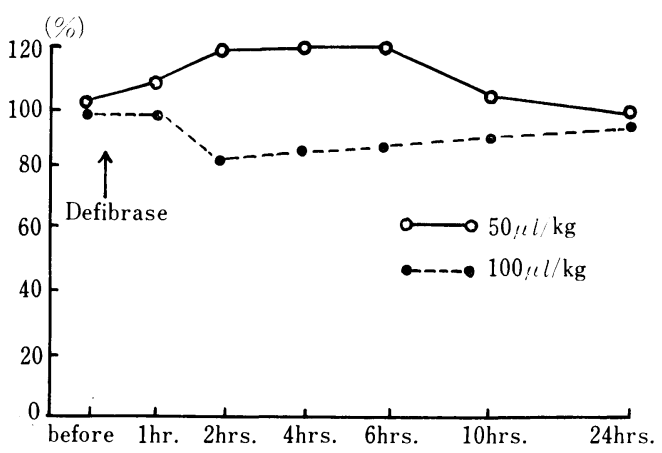

図 8 Factor II.

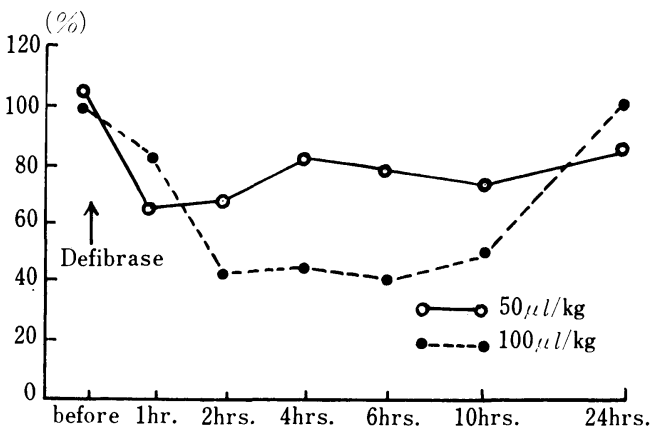

図 9 Factor V.

$\mu l / \mathrm{kg}$ 投与群では投与前值 $8.6 \pm 0.7$ 秒であり， 投与後 1 時間 で 10.0 秒前後 となり 2 時間後で は大部分が測定不能となった。 24 時間後では 9.0 秒前後を示しているものが多く，これは $100 \mu l / \mathrm{kg}$ 投与群でもほぼ同様である (図 5 ).

しかしこの值にもバラッキが多くみられた，そ こでフィブリノゲン量とプロトロンビン時間と の関係をみたところ，フィブリノゲン $150 \mathrm{mg} /$ $\mathrm{d} l$ 以上においてはプロトロンビン時間の変化 


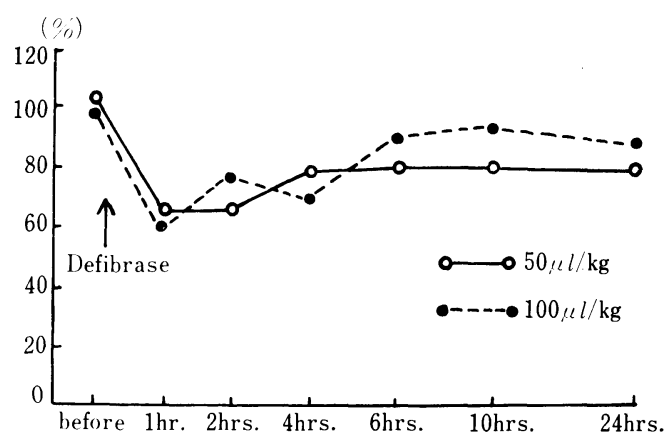

図 10 Factor VII-X.

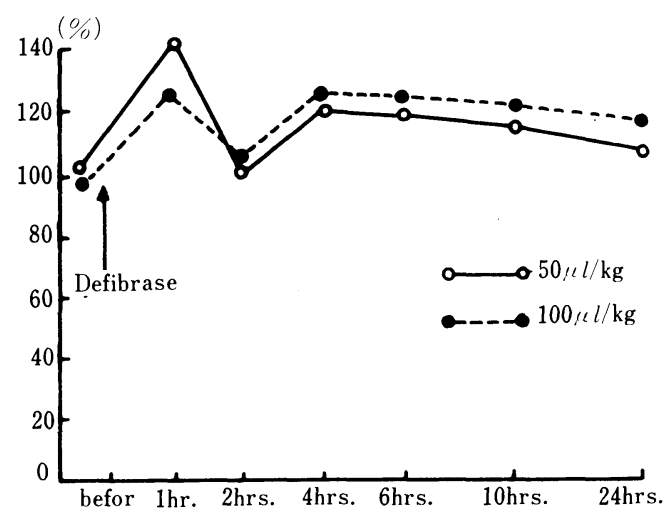

図 12 Factor IX.

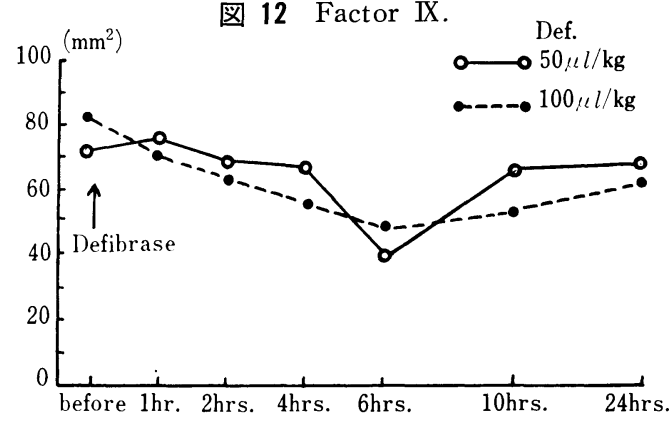

図 14 Plasminogen.

はほとんどみられないか，あっても 1 秒前後の 延長をみる程度であるが，フィブリノゲン 100 $\mathrm{mg} / \mathrm{d} l$ 以下では殆どの例がプロトロンビン時間 の著明な延長をみている（図6）.

(5) 活性化部分トロンボプラスチン時間 (APTT)：Defibrase $50 \mu \mathrm{l} / \mathrm{kg}$ 投与群では投与前值 は $17.5 \pm 1.6$ 秒でありフィブリノゲン減少とと もに延長するものもあるが，いずれもバラッキ が多く, 一定の傾向は見出せない。しかしフィ ブリノゲンとの関係をみるとフィブリノゲン

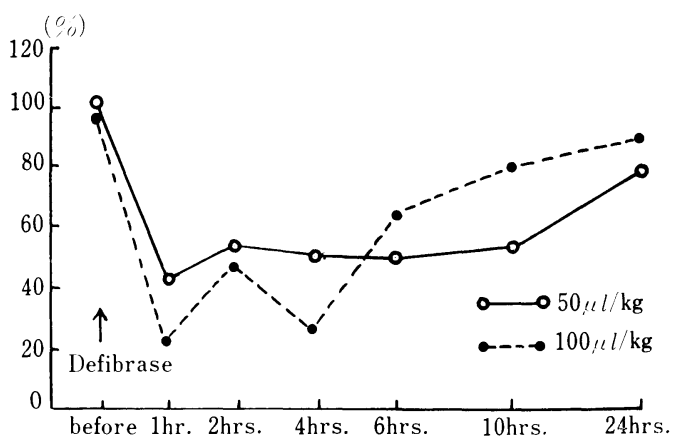

図 11 Factor VIII.

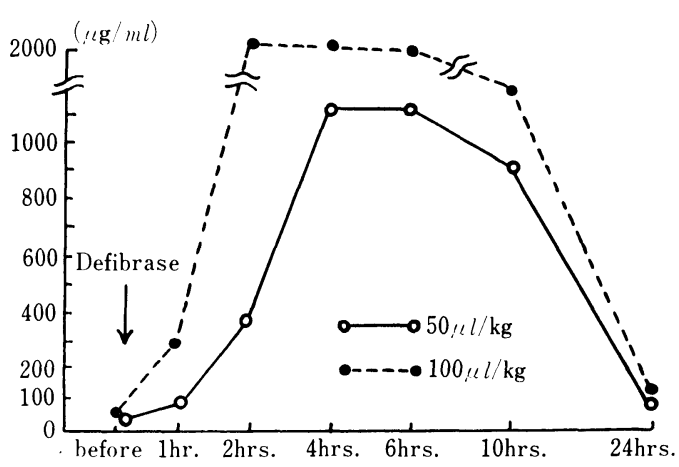

図 13 FDP.

$100 \mathrm{mg} / \mathrm{d} l$ 以下ではほとんどが 40 秒前後の延 長をみている（図 7 ).

(6) 凝固第 II 因子：投与前值を $100 \%$ と た場合, 両群ともに投与後の変化は少く, 特 に $50 \mu \mathrm{l} / \mathrm{kg}$ 投与群では $2 \sim 6$ 時間後の值が各々 120\%とやや増加する傾向がみられた（図 8 ).

(7) 凝固 $\mathrm{V}$ 第因子 : 投与後 1 時間 から 10 時 間にかけて $40 \sim 60 \%$ の低下がみられ, その程 度は投与量の多い群に著明である. しかし両群 とも 24 時間後では前值に回復している(図 9).

(8) 凝固第 VII-X 因子 : 投与後 1 時間より 4 時間までは約 $30 \sim 40 \%$ 低下がみられ，1時 間後は10〜20\%の低下がみられた（図10).

(9) 凝固第UII因子：両群ともに投与後 1 時間 より 4 時間まで約 $60 \%$ の低下を認め，24 時間 後では $10 \sim 20 \%$ 低下がみられた．投与量の 多い群が低下の程度も著明である（図11）.

(10) 凝固第IX因子：Defibrase 投与により低 下することなく, 両群ともにむしろ増加する傾 向がみられた（図12）。 


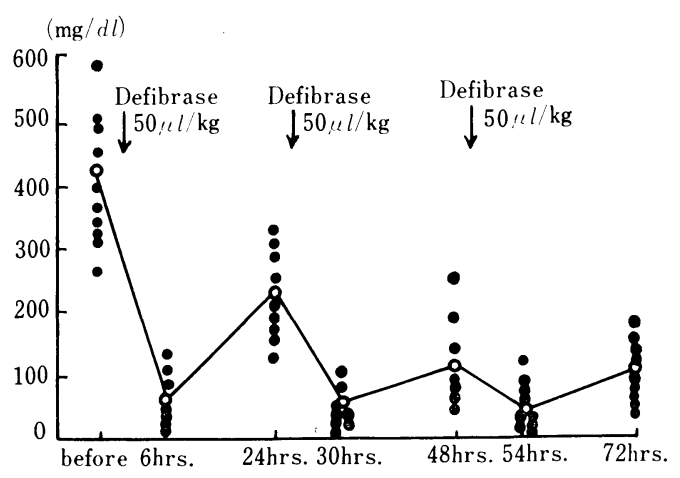

図 15 Fibrinogen (Defibrase $50 \mu \mathrm{l} / \mathrm{kg}$ ).

(11) FDP : 投与前 $10 \mu l / \mathrm{m} l$ 前後 であったが Defibrase $50 \mu \mathrm{l} / \mathrm{kg}$ 投与群では投与後 1 時間で $100 \mu \mathrm{g} / \mathrm{m} l$ 前後, 2 時間後で $400 \mu \mathrm{g} / \mathrm{m} l$ 前後, 4 時間以後 6 時間後までは $1,000 \mu \mathrm{g} / \mathrm{m} l$ 前後と 著明な増加を示した. しかし 10 時間以後次第 に減少して 24 時間後では $50 \sim 100 \mu \mathrm{g} / \mathrm{m} l$ とな った. また Defibrase $100 \mu \mathrm{l} / \mathrm{kg}$ 投与群では増 加の程度がさらに大きく, 投与後 2 時間から 6 時間まで $2,000 \mu \mathrm{g} / \mathrm{m} l$ 前後と著明な増加をみ た. 24 時間後では $100 \mu \mathrm{g} / \mathrm{m} l$ 前後と減少し, 50 $\mu l / \mathrm{kg}$ 投与群とほぼ同じ程度であった（図13）.

(12) プラスミノゲン: プラスミノゲンフリー 平板の溶解空面積によると両群ともに投与後徐 々に減少し. 6 時間後には前值に比べ $40 \sim 50$ \%の減少をみた. 24 時間後では 回復傾向をみ せているが, 前值に比べてやや低い值にとどま っている (図14).

(13) 活性プラスミン: 血浆中の活性プラスミ ンは 1 例が陽性を示したのみで, その他のもの は陰性であった。

(14) 抗プラスミン：測定值にバラッキが多い が，投与後 6 時間で前值に比べて $20 \sim 30 \%$ の
減少をみたが 24 時間後では増加する傾向にあ った.

(15) 硫酸プロタミン試験 : 両群ともに投与後 1 時間より 6 時間までの検体に陽性化がみられ たが，10 時間後では陰性であった.

2）Defibrase 1 日 1 回，3 日間投与につい $\tau$.

赤血球数, 血小板数に変化なく, PT, APTT, 各凝固因子については投与後 24 時間 までの変 動を同様に繰り返した.フィブリノゲンについ ては投与数が増えるに従ってその減少程度が安 定し， $50 \mu \mathrm{l} / \mathrm{kg}$ 投与群では最終投与より 24 時 間で $107 \pm 50 \mathrm{mg} / \mathrm{d} l, 100 \mu l / \mathrm{kg}$ 投与群では 60 $\mathrm{mg} / \mathrm{d} l$ 前後となった. また FDP についても投 与回数が増えるに従い, 増加の程度が小さくな る傾向がみられた（図15）.

\section{2. 血栓形成モデルによる Defibrase の血栓} 阻止効果.

(1) コントロール群 : $5 \% \mathrm{H}_{2} \mathrm{SO}_{4}$ 注入後 24 時間で大腿動脈を摘出し血栓形成状態を観察し たところ, 壁在性の血栓を中心として 10 頭中 8 頭に何らかの形で血栓形成を認め, その形成 率は $80 \%$ \%っむた（表 1).

(2) Defibrase 投与群 :

a ) Defibrase $100 \mu \mathrm{l} / \mathrm{kg}$ をモデル作成 6 時間 前に投与した群 2 頭では, 24 時間後剖検にて 血栓を認めなかった。

b) Defibrase $100 \mu l / \mathrm{kg}$ を 1 日 1 回で 2 日間 投与し, 最終投与より 24 時間後にモデル作成 した群 2 頭中 1 頭に剖検で壁在血栓を認めた.

c ) Defibrase $50 \mu l / \mathrm{kg}$ 投与を 1 日 1 回で 2 日間投与し，最終投与より 24 時間後にモデル 作成した群 6 頭には全例血栓形成を認めなかっ た. 全体としてDefibrase 投与群 10 頭中 1 頭に

表 1

\begin{tabular}{l|c|c|c|c}
\hline & Number & Thrombus & Nothrombus & Rate \\
\hline Control & 10 & 8 & 2 & $80 \%$ \\
\hline Defibrase & & & & \\
$100 \mu l / \mathrm{kg} \times 1$ day & 2 & 0 & 2 & $10 \%$ \\
$100 \mu l / \mathrm{kg} /$ day $\times 2$ days & 2 & 1 & 1 & \\
$50 \mu l / \mathrm{kg} /$ day $\times 2$ days & 6 & 0 & 6 & \\
\hline
\end{tabular}


表 2

\begin{tabular}{|c|c|c|c|c|c|}
\hline Defibrase & Fibrinogen & FDP & Bleeding & Hematoma & Thrombus \\
\hline $100 \mu \mathrm{l} / \mathrm{kg} \times 1$ day & $0(\mathrm{mg} / \mathrm{d} l)$ & $1,600(\mu \mathrm{g} / \mathrm{m} l)$ & 世 & + & - \\
\hline " & 0 & 2,000 & m & H & - \\
\hline $100 \mu l / \mathrm{kg} /$ day $\times 2$ days & 50 & 160 & $H$ & $H$ & - \\
\hline " & 40 & 280 & H & m & + \\
\hline $50 \mu \mathrm{l} / \mathrm{kg} /$ day $\times 2$ days & 140 & 180 & + & - & - \\
\hline " & 100 & 120 & + & - & - \\
\hline " & 60 & 300 & + & - & - \\
\hline " & 160 & 40 & - & - & - \\
\hline " & 40 & 120 & + & - & - \\
\hline " & 100 & 40 & + & - & - \\
\hline
\end{tabular}

血栓を認め，血栓形成率は $10 \%$ であった(表1).

3. Defibrase 投与中 の外科的侵襲による出 血.

a ) Defibrase $100 \mu \mathrm{l} / \mathrm{kg}$ の 6 時間前投与では 大腿動脈露出時に周囲組織からの oozing が多 くみられ,さらに $27 \mathrm{G}$ 注射針による 動脈への 穿刺後に同穿刺部位よりの出血が著明であり圧 迫止血は困難であった. これらに対してフィブ リノゲン粉末の局所散布は無効であり, 絹糸に よる針穴の結紮を行らに至った.このときのフ イブリノゲンは測定不能であり，FDP は 1,600 $\mu \mathrm{g} / \mathrm{ml}$ であった. また厳重な止血操作を行っ たにもかかわらず術後出血が多く，創部に $5 \times$ $10 \mathrm{~cm}$ の血腫形成がみられたものがあった。

b ）Defibrase $100 \mu \mathrm{l} / \mathrm{kg}$ 術前 2 日間投与群に おいても周囲組織より出血は多かったが，動脈 穿刺部位よりの出血は 10 分以上の圧迫で止血 したかにみえた。このときのフィブリノゲンは $50 \mathrm{mg} / \mathrm{d} l, \mathrm{FDP}$ は $160 \mu \mathrm{g} / \mathrm{ml}$ であった． 2 頭中 1 頭は約 $10 \times 15 \mathrm{~cm}$ の巨大な血腫を作り，剖検 にて動脈内壁に血栓を認めた。

c ）Defibrase $50 \mu \mathrm{l} / \mathrm{kg}$ の 術前 2 日間投与群 6 頭については創部出血は比較的多いが圧迫に て止血可能であり, 術後の血腫形成もみられな かった.このときのフィブリノゲンは $100 \pm 51$ $\mathrm{mg} / \mathrm{d} l$ であり, FDP は $139 \pm 109 \mu \mathrm{g} / \mathrm{m} l$ であっ た（表 2 ).

\section{III. 考 察}

Defibrase は fibrinogen から fibrinopeptide A
のみを分離して soluble fibrin とする thrombin like enzyme であり, これによって他の凝固因 子に変化を与えることなく血中のフィブリノゲ ンのみを低下させることができるといわれてい

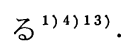

近年この thrombin like enzyme による脱線 維素療法がョーロッパを中心として注目され， その効果が期待されている2)3. 今回われわれ はこれが外科領域において使用可能かどうかを 中心として，実験的検討を行った.

\section{Defibrase (Bothrops atrox mara-}

\section{joensis）Lot. 696 の血液凝固および線 溶系に及ぼす影響について.}

本剂の投与により, 赤血球数, ヘマトクリッ 卜，血小板数に変化をみることなく血中のフィ ブリノゲンを著明に減少せしめることを確認し た. また凝固因子のらち第II，第IX因子につい ては軽度の増加がみられ，第 $\mathrm{V}$, 第 VII $-\mathrm{X}$, お よび第玍因子については一過性の減少をみた が，いずれも投与後 10 時間以内 の変化であっ た。しかしこれら凝固因子については変動がな いとする報告もあり ${ }^{12{ }^{14)}}$ ，詳細についてはさら に検討する必要があると思われる ${ }^{9}$.

PT および APTT についてはフィブリノゲ ンが $100 \mathrm{mg} / \mathrm{d} l$ 以上ある場合には成績にバラッ キがあり一定した傾向はつかみ得なかったが， $100 \mathrm{mg} / \mathrm{d} l$ 以下に減少した場合には著明な延長 を示す傾向があり，これはMartin ら ${ }^{7)}$ の報告と ほぼ同様である。

線溶系検査では FDP の増加が著明であり， 
これは投与後 4 時間から 6 時間に最高となっ た. 一方プラスミノゲンは軽度減少し, 活性プ ラスミンは検出されず，FDP の著明な増加を 裏づけるほどの線溶変化は認められなかった. また $1,000 \mu \mathrm{g} / \mathrm{m} l$ 以上に増加した FDP が 24 時 間後には $100 \mu \mathrm{g} / \mathrm{m} l$ 前後にまで回復し代謝が速 いことなどから，FDP として検出されたもの が果して線溶の結果によるものであるかどうか については疑問がある.さらに硫酸プロタミン 試験によれば Defibrase 投与後 6 時間をで陽性 となり，その後陰性化することから，この間に fibrinmonomer の出現が推定され，また時間的 にFDP の増減と一致することからも Defibrase によって分解されたフィブリノゲンの中間産物 である可溶性フィブリンモノマー複合体(SFMC) またはフィブリンモノマー, des A-fibrin など を FDP として検出しているとも考えられる.

Defibrase の投与量とフィブリノゲン量との 関係をみると, フィブリノゲンは投与後 4 時間 から 6 時閒に最低となり, その後徐々に回復す るというパターンをとり，全体として Defibrase 投与量の多い程低下は藷しく，24 時間後のフ ィブリノゲンの回復も少い。しかし1回投与で はその值に個体差と思われるバラッキが多く, 特にこれは投与前のフィブリノゲン量に大きく 関係しているようである.さらに投与を繰り返 すことで, 24 時間後のフィブリノゲンの回復 は安定してくる傾向がみられることは注目す心゙ きである。

\section{Defibrase の血栓阻止効果について.}

血栓形成 モデルによる 血栓形成率は $80 \%$ で あったが，Defibrase 投与群では $10 \%$ のみであ った。 また Defibrase を投与したにもかかわら ず血栓形成をみた 1 例については術後出血によ り形成された血腫の圧迫が一因として考えられ ることから，適切な投与量を選ぶことによっ て, さらに効果的な抗血栓性が得られるもの と考えられる ${ }^{6) 10)}$. われわれの成績によると， Defibrase $50 \mu l / \mathrm{kg}$ の術前 2 日間投与では比較 的安定したフィブリノゲン濃度 $(100 \pm 51 \mathrm{mg} /$ $\mathrm{d} l$ ) が得られており，しかもこのときの抗血栓 性は充分みられている。

\section{3. 外科的侵礱による出血について.}

Defibrase の副作用として最も危惧されるも のは出血である. 全実験例について, 投与後に 手術創部以外に出血をみたものはなかったが静 脈内注射後の針穴よりの出血には軽い圧迫が必 要であった。

Defibrase 投与中の手術による出血について Egberg $^{5)}$ や Olsson ら ${ }^{10)}$ は Defibrase によって 増加した FDP により血小板機能が抑制され，

これが術中, 術後出血の原因の一つであるとし て，FDPが正常化すればフィブリノゲンが 0 で あっても創部出血の危険性はないと報告してい る.しかし，われわれの成績では FDP が正常 化しているにもかかわらずフィブリノゲンが $50 \mathrm{mg} / \mathrm{d} l$ 以下では止血困難なことが多く, 安 全な止血を得るためには単にFDP の問題だけ でなく, 一定量のフィブリノゲンが必要である と考えており，その值は $100 \sim 50 \mathrm{mg} / \mathrm{d} l$ である. また，この值は前述した通り血栓阻止効果をも つ值でもあり，本実験においては Defibrase の 投与量として $50 \mu \mathrm{l} / \mathrm{kg}$ であった. しかし Defibrase の投与量とフィブリノゲンの低下の程度 については個体差や, 投与前のフィブリノゲン 量の違いなどでバラッキが多く, 適当な凝固系 の管理が必要である．検査としてはフィブリノ ゲンの定量を行うことが最良であろうが測定法 によっては正確さを欠くものもあり，また判定 に時間を要し臨床的に不向きな点もある ${ }^{14)}$. こ れらの意味から簡単な方法としては, PT ある いは APTT が延長を示すかどうかをみること で，おおよそのフィブリノゲン量 $(100 \mathrm{mg} / \mathrm{d} l$ 以下）を推定でき有効な方法であると考えてい る.

\section{おわりに}

Defibrase による脱線維素療法が血栓形成モ デル実験において完全に血栓を阻止するか否 か，また手術侵襲に対して大量出血もなく安全 に使用することが可能かどうかについて検討し た. その結果, Defibrase の適切な投与量の選 択によってその抗血栓性は充分認められさらに 出血の危険も少いことが判明した。 また, 本剤 
の投与により FDP の増加がみられたが線溶系 に及ぼす影響は比較的軽度であり血栓性疾患に 対して，これを予防することは可能でも，既に 形成されている血栓を積極的に溶解することに ついてはあまり期待できないと思われる。

脱線維素療法は本邦に扔いても比較的新しい 試みであり，未解決の部分も多いが，今後さら に検討を重ねていくことでその適応と有効性が 充分期待できるものと考えられる.

\section{文献}

1) Blombäck, B.: Studies on the action of thrombic enzyme on bovine fibrinogen as measured by $\mathrm{N}$-treminal analysis. Arkiv. Kemi., 12 ; 231, 1958.

2) Bell, W., et al. : Therapeutic defibrination in the treatment of thrombotic disease. Lancet, 1; 490, 1968.

3) Blombäck, M., et al. : Treatment of thrombotic disorders with reptilase. Throm. Diath. Haem. (Suppl), 45; 51, 1971.

4) Egberg, N., et al. : Clinical and experimental studies on Reptylase. Thromb. Diath. Haem. (Suppl), 47 ; 379, 1972.

5) Egberg, N., et al.:Platelet function induced by ADP and thrombin in Reptilase defibrinated dogs. Thrombos. Res., 1; 95, 1972.

6) Egberg, N., et al. : Coagulation studies in treated with defibrase. Acta. Med. Scand., $194 ; 291,1973$.

7) Martin, M., et al.:Die Wirkung der Defibrinierung auf Blutgerinnung und fibrinolytishes System. Defibrinierung mit thrombinähnlichen Schlangiftenzymen (Aktulle Probleme in der Angiologie : 26). M. Martin und W. Schoop, Verlag Hans Huber Bern Stuttgart Wien, 1975, p. 86.

8) Martin, M., et al. : Kontrolle der Fibrinogenbestimung unter defibrinierender Behandlung. Defibrinierung mit thrombinähnlichen Schlagengiftenzymen (Aktuelle Probleme in der Angiologie : 26). M. martin, und W. Schoop, Verlag Hans Huber Bern Stuttgart Wien., 1975, p. 166.
9）松田保他：Bothrox atrox の蛇毒 (Defibrase) による脱線維素療法. 医用醉素，3；40，1974.

10) Olsson, P., et al. : Studies on the bleeding tendency and on the possibility of surgery in states of Reptilase induced defibrinogeneration. Thromb. Diath. Haem. (Suppl), $1 ; 47,1971$.

11) Olsson, P.: The contribution of platelet and fibrnogen in the early development of experimental arterial and venous thrombi. Defibrinierung auf blutgerinnung und fibrinolytishes system (Aktuelle Probleme in der Angiologie : 26). M. Martin, und W. Schoop, Verlag Hans Huber Bern Stuttgart Wien, 1975, p. 108.

12) Osterud, B., et al. : Formation of intrinsic factor $\mathrm{X}$ activator activity with special reference to the role of thrombin. Brit. J. Haemat., 21 ; 643, 1971.

13) Stocker, K., et al. : Rapid detection of fibrinopeptides by bidimentional paper electophoresis. Thromb. Diath. Haem., 24 ; 248, 1970 .

14) Stocker, K., et al. : Characterization of defibrase. Defibrinierung mit thrombinähnlichen Schlangengiftenzymen (Aktuelle Probleme in der Angiologie : 26). M. Martin, und W. Schoop, Verlag Hans Huber Bern Stuttgart Wien, 1975, p. 45.

\section{$<$ Abstract $>$}

\section{Studies on possibility of surgery durling defibrination therapy}

\section{by}

Shin ISHIMARU, Masaki TOMONARI, Kinichi DOMEKI, Souske KOIKE, Yasuyuki FUJIWARA, Yasuyoshi HORIGUCHI, Kinichi FURUKAWA, Masatoshi TAKAHASHI and Michio FUJIMAKI*

$$
\text { from }
$$

Department of Surgery and* Clinical Pathology, Tokyo Medical college, Tokyo, Japan.

Defibrase is one of the thrombin like enzyme from bothrops atrox venom which couse fibrin 
formation by splitting off only fibrinopeptide A from fibrinogen. Defibrination therapy with this enzyme is expected to be a new type of anticoagulant therapy for thrombotic disorders.

In this paper, following investigations were carried out to study the possibility of surgery durling defibrination therapy with Defibrase;

1. Changes of coagulation and fibrinolysis systems effected by Defibrase.

Twenty one mongrel dogs were used. Eleven dogs were given $50 \mu \mathrm{l} / \mathrm{kg}$ of Defibrase(Bothrops atrox marajoensis) diluted in $100 \mathrm{~m} l$ saline intravenously for 1 hour. Another $10 \mathrm{dogs}$ were given $100 \mu \mathrm{l} / \mathrm{kg}$ of Defibrase in a similar manner. Blood samples were obtained by venous puncture before and after infusion, and following blood examinations were carried out; red blood cell, hematcrit, platelet count, fibrinogen level, prothrombin time, activated partial thromboplastin time, coagulation factors (II, V, VII-X, VII, IX), fibrin and fibrinogen degradiation products (FDP), plasminogen, plasmin, antiplasmin and protamin sulfate test.

2. Fibrinogen levels that prevent thrombosis on experimental model of thrombus formation.

Twenty mongrel dogs were used. In a series of $10 \mathrm{dogs}$, endotheriums of femoral arteries were injured by $5 \%$ sulfulic acid for thrombus formation as control. In another series of 10 dogs, Defibrase therapy was done for 6 hours to
3 days before the experiment to achieve a low fibrinogen concentration, and thrombus formation was investigated after that.

3. Hemorrhagic tendency.

Observation for hemorrhagic tendency following surgery under the defibrination therapy was done. Plasma fibrinogen concentration was markedly decreased without any change of RBC, $\mathrm{Ht}$ and platelet count after infusion of Defibrase. Coagulation factor II and IX were slightly increased. Factor V, VII-X and VII were decreased but they recovered after 24 hours. Prothrombin time and activated partial thromboplastin time were prolonged at fibrinogen levels of below $100 \mathrm{mg} / \mathrm{d} l$. FDP was increased markedly for 4 to 6 hours after infnsion, though changes of plasminogen levels which supported increase of FDP were not observed.

Olsson pointed out that the hemorrhagic tendency durling defibrination therapy was not due to the lack of fibrinogen, but to the anticoagulant effect of FDP, and hemorrhage did not occur when FDP had fallen to low concentration. In our experiments, however, bleeding was durable in many cases when fibrinogen level was under $50 \mathrm{mg} / \mathrm{d} l$ inspite of FDP was in normal limit. For hemostasis, some levels of fibrinogen is needed besides FDP. The level of fibrinogen for certain hemostasis and effective anticoagulant therapy was 50 to $100 \mathrm{mg} / \mathrm{d} l$. 